\title{
Karine Deslandes, Regards français sur le conflit nord-irlandais
}

\section{Wesley Hutchinson}

\section{(2) OpenEdition \\ 1 Journals}

\section{Electronic version}

URL: http://journals.openedition.org/etudesirlandaises/3855

DOI: 10.4000/etudesirlandaises.3855

ISSN: 2259-8863

\section{Publisher}

Presses universitaires de Caen

\section{Printed version}

Date of publication: 30 June 2014

Number of pages: $229-230$

ISBN: 978-2-7535-3449-0

ISSN: 0183-973X

\section{Electronic reference}

Wesley Hutchinson, « Karine Deslandes, Regards français sur le conflit nord-irlandais », Études irlandaises [Online], 39-1 | 2014, Online since 30 June 2016, connection on 22 September 2020. URL : http://journals.openedition.org/etudesirlandaises/3855; DOI : https://doi.org/10.4000/ etudesirlandaises.3855

\section{(c) (1) ()}

Études irlandaises est mise à disposition selon les termes de la Licence Creative Commons Attribution - Pas d'Utilisation Commerciale - Partage dans les Mêmes Conditions 4.0 International. 
Karine Deslandes, Regards français sur le conflit nord-irlandais, Frankfurt am Main, Peter Lang, 2013. ISBN 978-3-631-64593-2.

This book, which is the fifth volume in the "Studies in Franco-Irish Relations" series edited by Eamon Maher, is an extremely interesting and useful examination of the coverage of the Northern Ireland conflict in the French press over the period running from 1969 to the signing of the Belfast Agreement in 1998. The text is based on research carried out at the University of Ulster (Coleraine). It looks at the way the French papers approach the Northern Ireland issue within four principal frames: the representations of the origins of the conflict; British policy initiatives; paramilitary violence; and the search for peace.

Broadly speaking, Deslandes identifies a series of areas and a number of events that attracted the attention of the French press on the Northern Ireland conflict. After showing the various shades of bias in the French press's framing of specific events through a detailed and convincing presentation of extracts from her primary source material, she then goes on to challenge those readings through an exploration of her secondary sources and personal comment. The text will be of particular interest to a French public as it successfully decodes the ways in which French attitudes to the North have been formed (some would argue, deformed) over the years, while at the same time interfacing with on-going preoccupations inside France itself.

The book is the result of very wide-ranging and yet detailed research, the density of the work on primary sources being evident from the comprehensive footnotes that back up the text. The corpus chosen is broad in terms both of the period covered - some thirty years - and the political spread. Deslandes looks systematically at all the main papers: Le Monde, Le Figaro, Libération, L'Humanité, Le Nouvel Observateur, Le Point, L'Express, La Croix, etc. but also brings in other sources such as the French Protestant weekly, Réforme, whose readership would have particular reasons for being interested in Northern Ireland.

In the course of the book, Deslandes illustrates a close understanding of the complexities involved in decoding the Northern Ireland situation. But the most interesting feature of the work is the way she demonstrates her ability to explore how the history and contemporary preoccupations of the French audience colour their understanding of and interest in events there.

Thus, Deslandes shows how, at the beginning of the Troubles, French journalists often lacked the necessary frames with which to decode what has happening on the ground. The inevitable reflex was to identify sources for analogy in French history and in the political orthodoxies of the moment that would give them - and their readers - handles on an otherwise opaque situation. The result, inevitably, was oversimplification and distortion. Thus, the general situation was 
looked at - with considerable intellectual condescension - as a latter-day "guerre de religion". Although the French have since been led to review their position, at the time they found it quite unimaginable that religion might influence, indeed motivate, political action in the contemporary world. Another frame that was called on was that of decolonisation, especially Algeria which was used as a template to "explain" the North: according to this analogy, a model which for many had the advantage of terminating in (British) withdrawal, all that was needed was for a new de Gaulle to sort out the Protestant Pieds-Noirs and, presumably, pack them back off to... England? Similarly, Stormont's policies like internment were translated in terms of the rafles by the Vichy authorities in "occupied" France; this was to be a frame that was to be picked up again in the early 1980s and pushed into the readings of the H-Blocks as concentration camps - much to the disgust of the Jewish community. Such initial framing was to have a deep impact on the way the French public was to interpret events in the North on an on-going basis.

Deslandes also shows how readings of events in the North are coloured by the "conjuncture française", i.e. when political events in the North actually coincide with on-going events inside France ( $c f$. the hunger strikes and the presidential elections of 1981), thus adding a supplementary layer to the supposed historical parallels (wars of religion, Nazi occupation, collaboration, Algeria). When such a blurring of issues takes place, it is often difficult to see what the focus of attention really is - the situation in the North or the internal French debate. At other times, the realities of the North impinge directly on France in a less abstract manner as when "les Irlandais de Vincennes" (1982) are accused of involvement in an international terror network ( $c f$. the attack on the rue des Rosiers) and many in the French press take advantage of the situation to remind their readers solemnly that "le combat des nationalistes irlandais n'est nullement assimilable au terrorisme" (151); or again in the Eksund incident (1987), involving arms shipments from Libya, which, Deslandes argues, illustrates a clear left-right split in terms of the treatment of republican violence, papers like Le Figaro highlighting IRA links to Libya and papers like Le Monde or Libération preferring to look the other way.

Indeed, a reading of the subtext of the book raises fundamental questions about the significant ellipses in the story, whether this involves (lack of) coverage of specific incidents that fail to correspond to the line a given journalist or paper wishes to sell, or entire periods, for example 1975-1978, when the normalisation of violence in the North is insufficiently high-profile to attract significant media attention for a French audience. As always, a study of the gaps in publication is very instructive about those who supply us with information. In many ways, it is indeed as interesting as what they choose not to tell us when they do decide to write.

Inevitably, the French press's readings of British policy, political violence and the peace process reflect the underlying ideologies of the various papers. However, 
those readings can be given a particular colouring thanks to the voice, the "signature" of a particular journalist. Here an obvious example is someone like Sorj Chalendon who pushes Liberration's idealisation of the republican cause on to the level of a personal crusade. Another example would be René Fréchet, the wellknown Irish Studies specialist who lectured at Paris 3 and who covered Northern Ireland for the French Protestant weekly, Réforme. Fréchet is worth mentioning in that he was often a lone voice on the North choosing as he did to go against received wisdom and the dominant prêts-à-penser to look at the concerns of the unionist community in a more balanced, less caricatural light than many of his colleagues.

Thus, Deslandes' attention to political and cultural subtexts, her sensitivity to the multiplicity of possible readings of a given situation and her ability to work on the interface between two evolving political realities make the book a most valuable contribution to work in French on the Northern Ireland conflict. It is certain to stimulate further research in an area which has not received sufficient attention.

Wesley Hutchinson

Université Sorbonne Nouvelle-Paris 3

Harry White \& Barra Boydell (eds.), Encyclopaedia of Music in Ireland, Dublin, UCD Press, 2013, 1152 p., ISBN 978-1-90635-978-2

Over ten years in the making, the Encyclopaedia of Music in Ireland (EMIR), is one of the many projects made possible by the Irish-American businessman Chuck Feeney, and notably co-funded by the Irish Research Council. Inspired by the 1980 New Grove Dictionary of Music and Musicians, and the 1981 Encyclopedia of Music in Canada, it aims at being "the first comprehensive attempt to chart Irish musical life across recorded history", and was edited by two of the most distinguished professors of music in Ireland, Harry White and Barra Boydell.

With 2000 articles written by 240 contributors for two volumes, printed on quality paper and presented in a splendid hard case, EMIR has been several times described by the authors themselves as a "map of Irish musical experience", albeit "not an exhaustive index or directory": the selection process was thus a challenging and lengthy one, completed by a board of editors chaired by Gerard Gillen, another distinguished professor of Music in Ireland, on the basis of "musical significance rather than fame", as summed up by Harry White. 